\title{
Project Management Plan for the INEL Technology Logic Diagrams
}

Mark J. Rudin

Published October 1992

\author{
Idaho National Engineering Laboratory \\ EG\&G Idaho, Inc. \\ Idaho Falls, Idaho 83415
}




\section{Project Management Plan for the INEL Technology Logic Diagrams}

EGG-WTD-10468

Reviewed by:
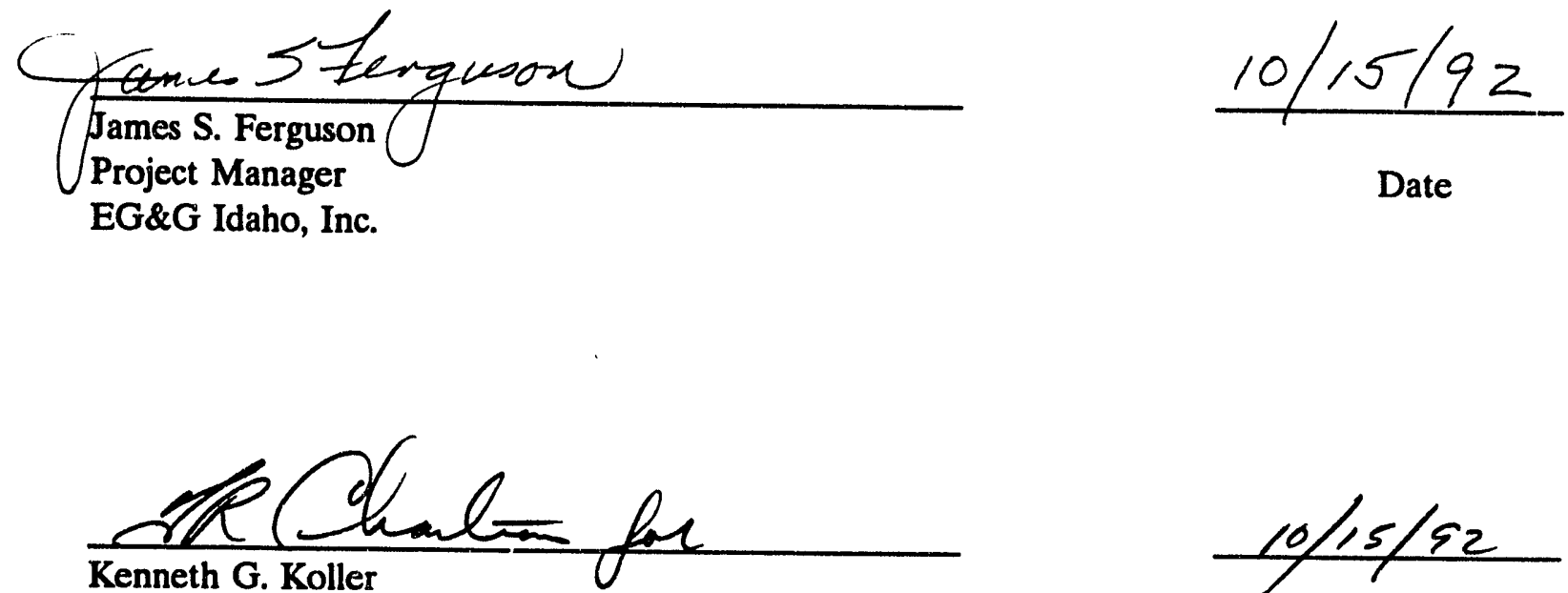

Kenneth G. Koller

Unit Manager

EG\&G Idaho, Inc.

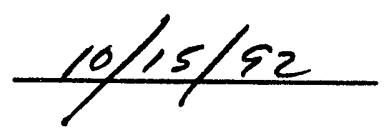

Date

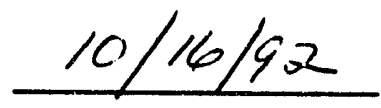

Date 


\begin{abstract}
This Project Management Plan (PjMP) describes the elements of project planning and control that apply to activities outlined in Technical Task Plan (TTP) ID-121117, "Technology Logic Diagrams For The INEL." The work on this project will be conducted by personnel in EG\&G Idaho, Inc.'s Waste Technology Development Program. Technology logic diagrams represent a formal methodology to identify technology gaps or needs within Environmental Restoration/Waste Management Operations, which will focus on Office of Environmental Restoration and Waste Management (EM-50) research and development, demonstration, test, and evaluation efforts throughout the U.S. Department of Energy complex. This PjMP describes the objectives, organization, roles and responsibilities, workscope and processes for implementing and managing the technology logic diagram for the Idaho National Engineering Laboratory project.
\end{abstract}




\section{SUMMARY}

This Project Management Plan describes the elements of project planning and control that apply to the technology logic diagrams for the Idaho National Engineering Laboratory (INEL) project according to INEL and EG\&G Idaho, Inc. procedures and requirements. The management processes, programmatic and technical objectives, schedules, and other key elements in project management are addressed. Key functions in support of project management such as cost estimates, reporting, configuration management, regulatory coordination, and health and safety considerations are presented. 


\section{ACKNOWLEDGEMENTS}

The author would like to acknowledge the following individuals for their major contributions in the preparation of this Project Management Plan: R. L. Kibbe, R. L. Fellows, M. C. O’Brien, and J. S. Ferguson. 


\section{CONTENTS}

ABSTRACT $\ldots \ldots \ldots \ldots \ldots \ldots \ldots \ldots \ldots \ldots \ldots \ldots \ldots \ldots \ldots \ldots \ldots \ldots \ldots \ldots \ldots \ldots$

SUMMARY $\ldots \ldots \ldots \ldots \ldots \ldots \ldots \ldots \ldots \ldots \ldots \ldots \ldots \ldots \ldots \ldots \ldots$

ACKNOWLEDGEMENTS $\ldots \ldots \ldots \ldots \ldots \ldots \ldots \ldots \ldots \ldots \ldots \ldots \ldots \ldots \ldots \ldots$ vii

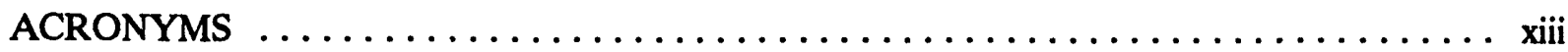

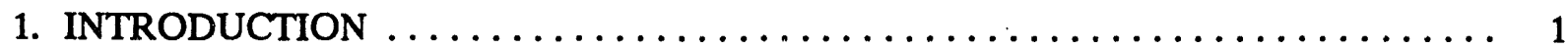

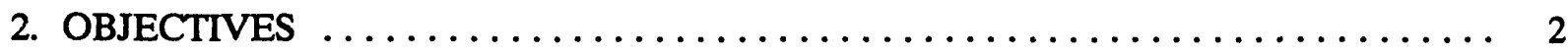

3. MANAGEMENT ORGANIZATION AND RESPONSIBILITIES $\ldots \ldots \ldots \ldots \ldots \ldots$

3.1 External INEL Organization and Responsibilities $\ldots \ldots \ldots \ldots \ldots \ldots \ldots \ldots$

3.2 Internal INEL Organization and Responsibilities $\ldots \ldots \ldots \ldots \ldots \ldots \ldots \ldots$

3.2.1 Technical Program Manager $\ldots \ldots \ldots \ldots \ldots \ldots \ldots \ldots \ldots \ldots \ldots \ldots \ldots$

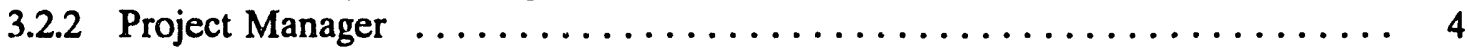

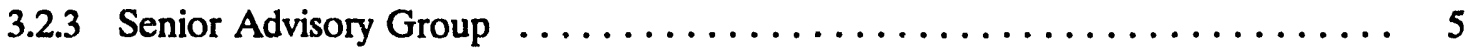

3.2.4 Planning, Oversight, and Coordination Committee $\ldots \ldots \ldots \ldots \ldots \ldots \ldots$

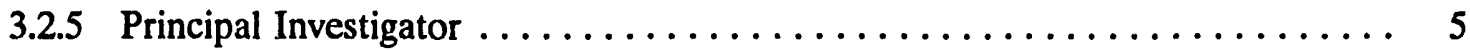

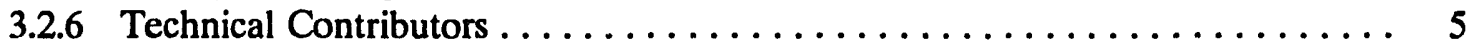

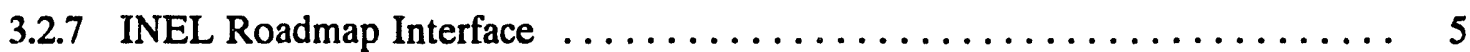

3.2 .8 Computer Support $\ldots \ldots \ldots \ldots \ldots \ldots \ldots \ldots \ldots \ldots \ldots \ldots \ldots \ldots \ldots \ldots$

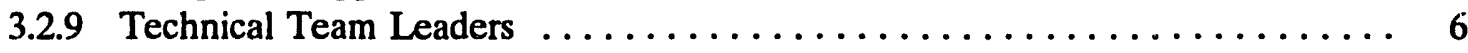

3.2.10 Technical Team Members $\ldots \ldots \ldots \ldots \ldots \ldots \ldots \ldots \ldots \ldots \ldots \ldots \ldots \ldots$

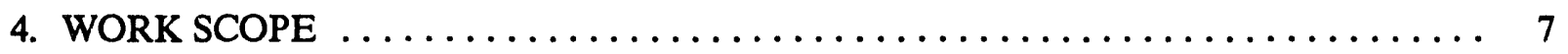

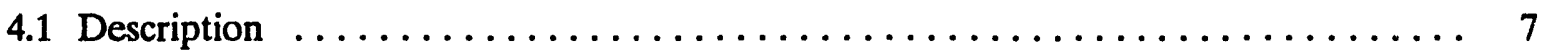

4.2 Filter Portion of Technology Logic Diagrams $\ldots \ldots \ldots \ldots \ldots \ldots \ldots \ldots \ldots$

4.3 Technology Portion of Technology Logic Diagrams $\ldots \ldots \ldots \ldots \ldots \ldots \ldots \ldots .9$

4.4 Technology Logic Diagrams $\ldots \ldots \ldots \ldots \ldots \ldots \ldots \ldots \ldots \ldots \ldots \ldots \ldots \ldots \ldots$

4.5 Deliver Technology Logic Diagram Report .................. 11

4.6 ER and WMO Roadmap Support/Integration $\ldots \ldots \ldots \ldots \ldots \ldots \ldots \ldots \ldots$ 
5. WORK BREAKDOWN STRUCTURE AND RESPONSIBILITY ASSIGNMENT $\ldots \ldots 12$

5.1 Project Work Breakdown Structure $\ldots \ldots \ldots \ldots \ldots \ldots \ldots \ldots \ldots \ldots \ldots \ldots \ldots$

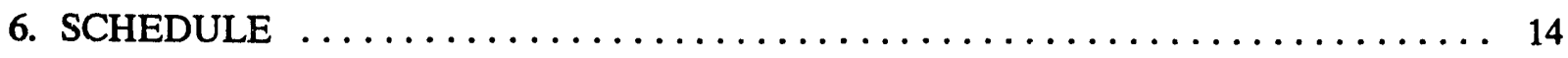

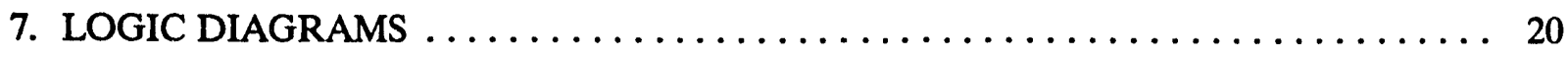

8. PERFORMANCE CRITERIA $\ldots \ldots \ldots \ldots \ldots \ldots \ldots \ldots \ldots \ldots \ldots \ldots \ldots \ldots \ldots \ldots$

9. COST AND MANPOWER ESTIMATES $\ldots \ldots \ldots \ldots \ldots \ldots \ldots \ldots \ldots \ldots \ldots \ldots$

10. PROJECT FUNCTIONAL SUPPORT REQUIREMENTS $\ldots \ldots \ldots \ldots \ldots \ldots \ldots$

11. PROJECT MANAGEMENT, MEASUREMENTS, AND PLANNING AND

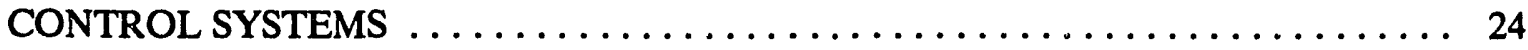

12. INFORMATION AND REPORTING $\ldots \ldots \ldots \ldots \ldots \ldots \ldots \ldots \ldots \ldots \ldots$

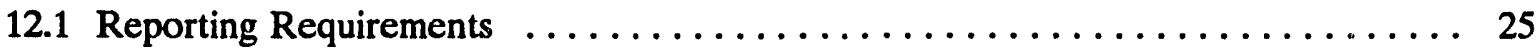

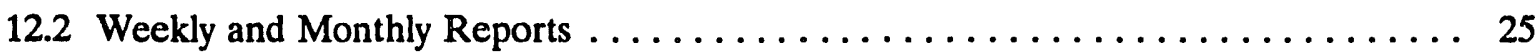

13. SYSTEM ENGINEERING MANAGEMENT PLAN $\ldots \ldots \ldots \ldots \ldots \ldots \ldots \ldots$

14. CONFIGURATION MANAGEMENT $\ldots \ldots \ldots \ldots \ldots \ldots \ldots \ldots \ldots \ldots \ldots \ldots$

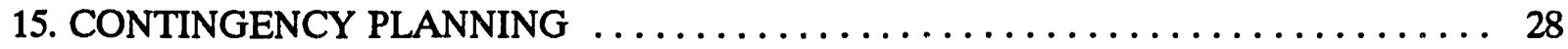

16. QUALITY ASSURANCE $\ldots \ldots \ldots \ldots \ldots \ldots \ldots \ldots \ldots \ldots \ldots \ldots \ldots \ldots \ldots$

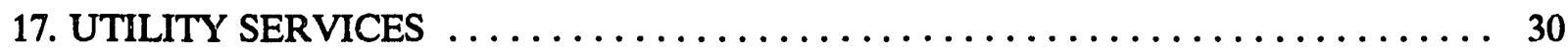

18. DECISION RESPONSIBILITY MATRIX $\ldots \ldots \ldots \ldots \ldots \ldots \ldots \ldots \ldots \ldots \ldots \ldots$

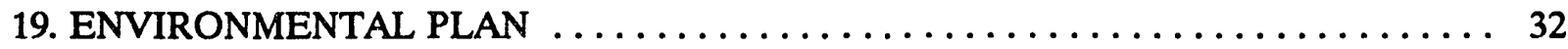

20. HEALTH AND SAFETY PLAN $\ldots \ldots \ldots \ldots \ldots \ldots \ldots \ldots \ldots \ldots \ldots \ldots \ldots \ldots$

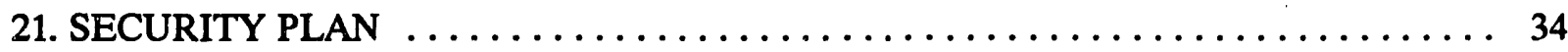

22. TECHNOLOGY TRANSFER $\ldots \ldots \ldots \ldots \ldots \ldots \ldots \ldots \ldots \ldots \ldots \ldots \ldots \ldots$

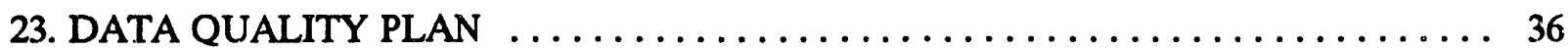

24. ACQUISITION AND ASSISTANCE PLAN $\ldots \ldots \ldots \ldots \ldots \ldots \ldots \ldots \ldots \ldots$ 
25. TEST AND EVALUATION PLAN $\ldots \ldots \ldots \ldots \ldots \ldots \ldots \ldots \ldots \ldots \ldots \ldots$

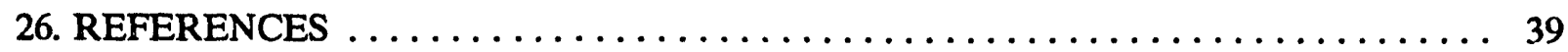

Appendix A-Portion of ORNL K-25 Technology Logic Diagram ............. A-1

Appendix B-Technology Logic Diagram Data Sheet Example $\ldots \ldots \ldots \ldots \ldots \ldots \ldots \ldots$ B-1

\section{FIGURES}

1. INEL TLD external organizational chart $\ldots \ldots \ldots \ldots \ldots \ldots \ldots \ldots \ldots \ldots \ldots \ldots \ldots \ldots \ldots$

2. INEL TLD internal organization chart $\ldots \ldots \ldots \ldots \ldots \ldots \ldots \ldots \ldots \ldots \ldots \ldots \ldots$

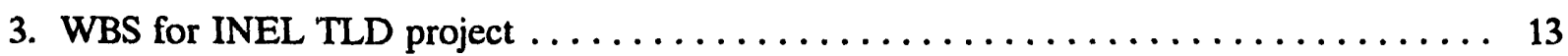

\section{TABLES}

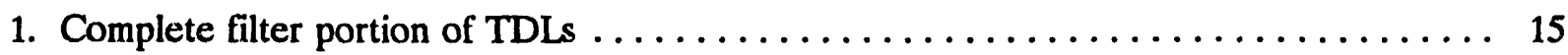

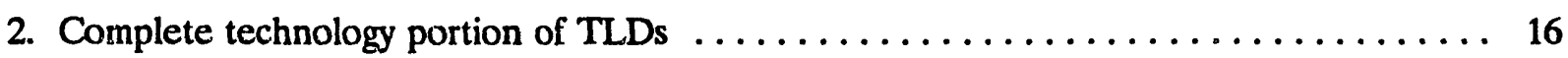

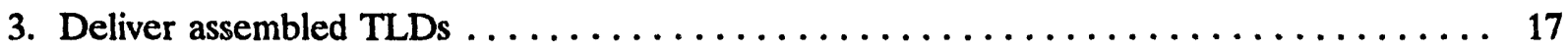

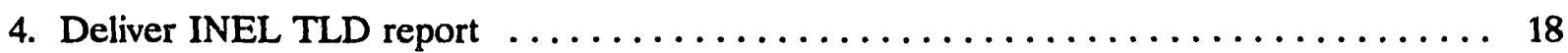

5. INEL ER and WMO roadmapping support $\ldots \ldots \ldots \ldots \ldots \ldots \ldots \ldots \ldots \ldots \ldots$

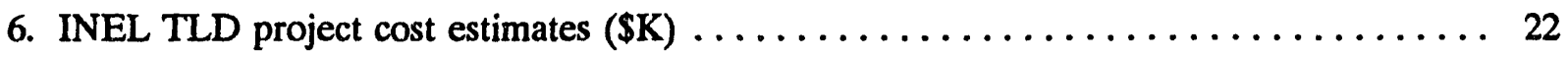

7. INEL TLD project labor estimates (full-time equivalent) $\ldots \ldots \ldots \ldots \ldots \ldots \ldots \ldots$ 


\section{ACRONYMS}

\begin{tabular}{|c|c|}
\hline CAPS & Cost and Planning System \\
\hline $\mathrm{CCB}$ & Change Control Board \\
\hline DOE-HQ & U.S. Department of Energy Headquarters \\
\hline DOE-ID & U.S. Department of Energy Idaho Field Office \\
\hline EM & Office of Environmental Restoration and Waste Management \\
\hline EPA & Environmental Protection Agency \\
\hline ER & Environmental Restoration \\
\hline FFACO & Foteral Facility and Consent Order \\
\hline INEL & Iuaho National Engineering Laboratory \\
\hline NEPA & National Environmental Policy Act \\
\hline ORNL & Oak Ridge National Laboratory \\
\hline OTD & Office of Technology Development \\
\hline OU & Operable Unit \\
\hline PD & Program Directive \\
\hline PMB & Performance Measurement Baseline \\
\hline PjMP & Project Management Plan \\
\hline RI/FS & Remedial Investigation/Feasibility Study \\
\hline TD & Technology Development \\
\hline TLD & Technology Logic Diagram \\
\hline TPM & Technical Program Manager \\
\hline TPO & Technical Program Officer \\
\hline TTP & Technical Task Plan \\
\hline
\end{tabular}




$\begin{array}{ll}\text { WAG } & \text { Waste Area Group } \\ \text { WBS } & \text { Work Breakdown Structure } \\ \text { WMO } & \text { Waste Management Operations } \\ \text { WTD } & \text { Waste Technology Development } \\ \text { WTDP } & \text { Waste Technology Development Programs }\end{array}$




\section{Project Management Plan for the INEL Technology Logic Diagrams}

\section{INTRODUCTION}

The Office of Technology Development (OTD) adopted a needs-driven approach to identify and develop technologies for their successful implementation into Office of Environmental Restoration and Waste Management, EM-30 and EM-40 activities. In FY 1991, the Office of Environmental Management selected the Hanford Site to utilize a technology logic diagram (TLD) process that identified and characterized links between U.S. Department of Energy (DOE) EM needs and research activities. The Hanford effort resulted in the publication of a report, The. Hanford Model: Environment Cleanup Problems, Science, and Technology Needs, and Facility Requirements, ${ }^{1}$ wisich serves as a preliminary model to help other DOE sites define the r research, development, and demonstration needs in the area of Environmental Restoration (ER) an? Laboratory (ORNL) modified the TLD appro the used at Hanford and applied the methodology to identify Decontamination and Decommissioning (D\&D) technology gaps or needs at its K-25 site during FY 1992.

The Idaho National Engineering Laboratory (INEL) and ORNL have been selected by EM-54 to generate TLDs at their respective sites during FY 1993. The INEL will generate TLDs for its ER Waste Area Groups (WAGs) 1 through 7 and 10, and ORNL will develop TLDs for its X-10 site. The ultimate purpose of this U.S. Department of Energy Headquarters (DOE-HQ) driven initiative is to identify ER and WMO cradle-to-grave technology needs or gaps at the two sites and to focus on EM-50 research and development activities throughout the DOE complex that can be integrated with the INEL ER/WMO roadmapping efforts to meet the overall INEL cleanup mission.

This Project Management Plan (PjMP) identifies the management processes and administrative controls required to perform activities outlined in Technical Task Plan (TTP) ID-121117, "Technology Logic Diagrams For The INEL." This activity is referred to as the "project" in the remainder of this document. The processes of project management addressed in this PjMP are in accordance with the EG\&G Idaho, Inc. Company Procedures Manual, Vol. III Section 20.9, and in accordance with the intent of DOE Order 4700.1, "Project Management System," 2250.1C, "Cost and Schedule Control Systems Criteria," and DOE Order 5480.19, "Conduct of Operations." 


\section{OBJECTIVES}

The INEL will generate TLDs for its ER Technology Development (TD) WAGs 1 through 7 and 10. TI.Ds will provide the mechanism to (a) identify and prioritize programmatic and institutional drivers that may affect INEL ER and WMO needs and/or TD activities, (b) identify specitic INEL ER and WMO technology gaps, (c) assess if existing state-of-the-art technologies from the private sector, DOE complex, and other Federal agencies can potentially meet those needs, (d) identify ER and WMO TD needs, and (e) provide input to developing a long-term TD strategy that can be integrated. with the INEL ER and WMO roadmapping efforts and issue resolution activities to meet the overall INEL cleanup mission.

The terms tech.zology gap and TD need hold distinct definitions within this project. A technology gap is defined as the inability to meet a particular ER and WMO problem without significantly modifying currently available technologies. A TD need is defined as the developmental work (e.g., research and development, and/or demonstration) required to fill a technology gap. 


\section{MANAGEMENT ORGANIZATION AND RESPONSIBILITIES}

\subsection{External INEL Organization and Responsibilities}

Personnel in EG\&G Idaho's Waste Technology Development Program (WTDP) will assume responsibility for performing activities outlined in TTP ID-121117 and described in this PjMP. Mechanisms for these personnel to interface with DOE-HQ OTD, U.S. Department of Energy Idaho Field Office (DOE-ID), other DOE field offices, and internal and external INEL organizat $s$ are provided by the EG\&G Idaho Technical Program Manager (TPM). Program guidance for this project is directed from OTD (EM-54) through the DOE-ID Technical Program Officer (TPO), DOE-ID project manager, and TPM to the project manager (see Figure 1).

A TLD Steering Group has been assembled by DOE-HQ OTD to provide management oversight into TLD efforts conducted throughout the DOE complex, including those at is INEL and the ORNL. The TLD Steering Group reports to the DOE-HQ Program Manager, EM-54. Group members include representatives from Kaiser Engineering, Hanford, EG\&G Corporate ${ }_{i}$ Argonne National Laboratory, and EG\&G Idaho. The INEL TLD project manager will schedule periodic presentations to the TLD Steering Group to facilitate their feedback and input to project progress.

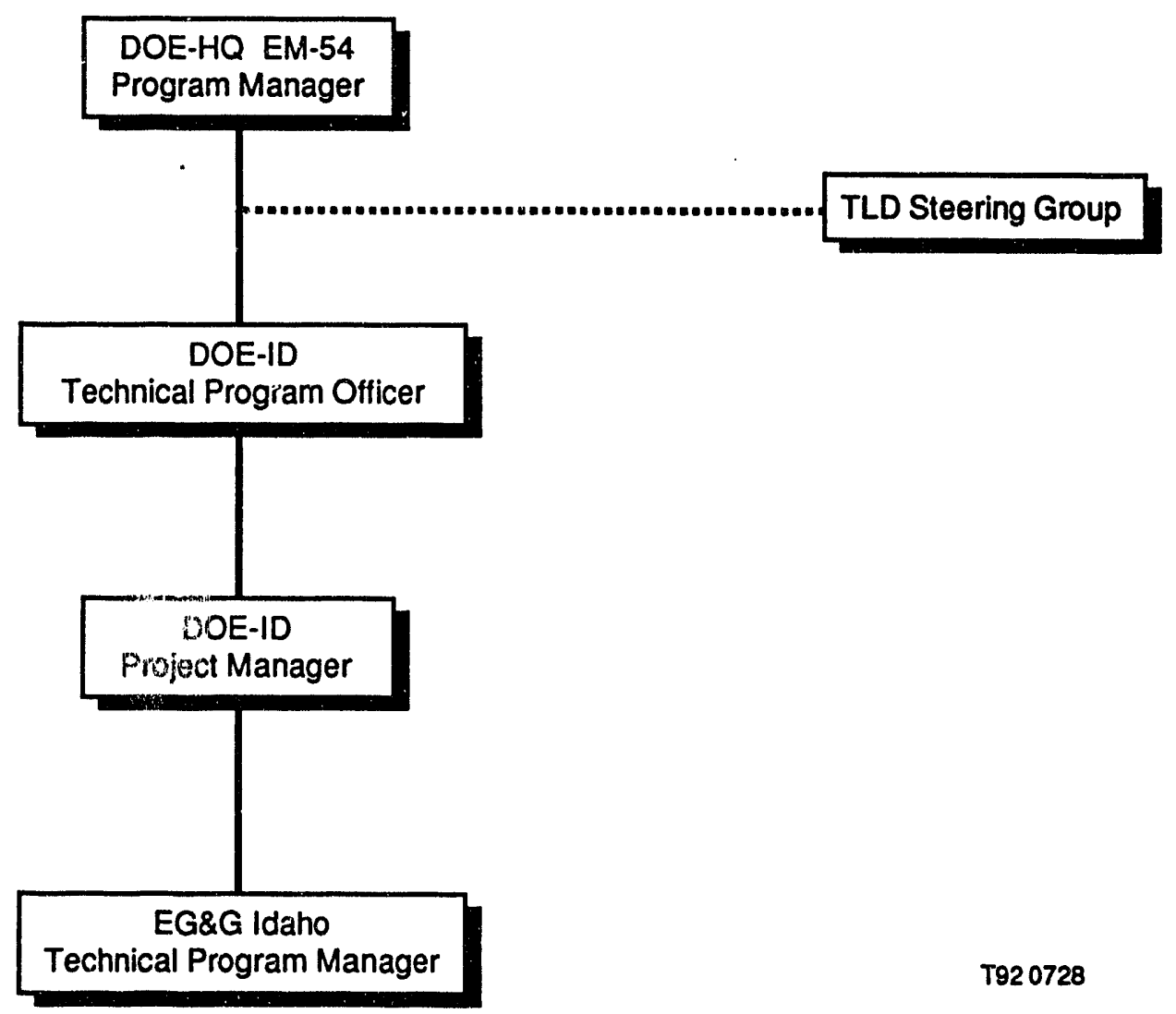

Figure 1. INEL TLD external organizational chart. 


\subsection{Internal INEL Organization and Responsibilities}

The internal organizational structure, elements, and responsibilities for this project are as follows (see Figure 2):

\subsubsection{Technical Program Manager}

The Technical Program Manager (TPM) is responsible for ensuring that deliverables, project cost control, and reporting are consistent with the directives and guidance given by the TPO. The TPM is responsible for maintaining line management accountability to ensure that the activities and tasks defined as set forth in the approved TTP meet customer and programmatic requirements.

\subsubsection{Project Manager}

The project manager is responsible for the programmatic integrity of the project. The project manager is responsible for managing the technical work scope, cost, and schedule performance in accordance with TTP ID-121117. The project manager reports to the responsible program manager assigned to the project. On programmatic progress, the TPM makes recommendations affecting budgets and schedules, and suggests corrective actions as appropriate. In addition, the project manager must establish direct communication interfaces with INEL WAG managers to facilitate the transfer of information between ER and TD.

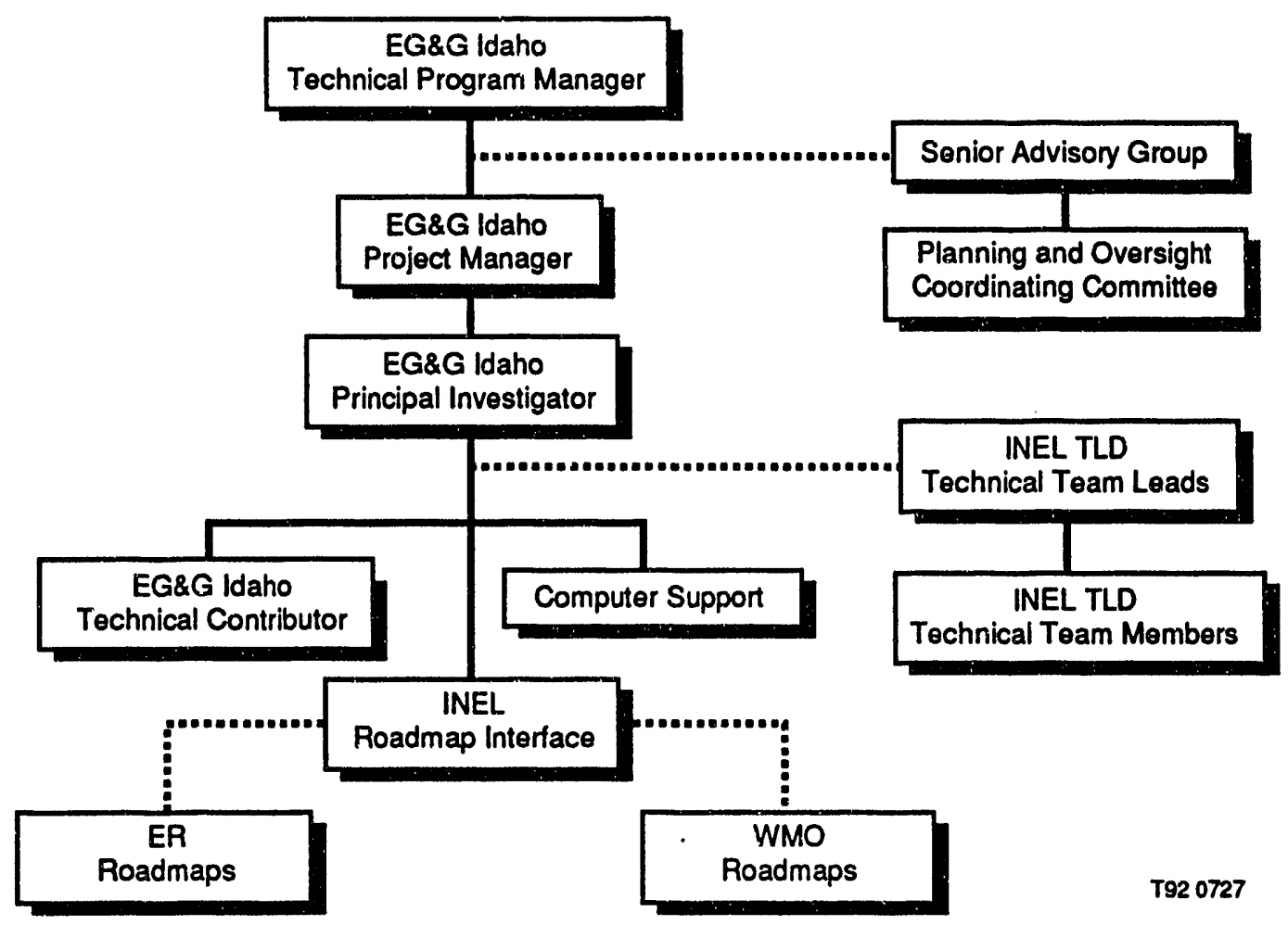

Figure 2. INEL TLD internal organization chart. 


\subsubsection{Senior Advisory Group}

The INEL TLD Senior Advisory Group participants provide oversight to the progress of the project and review the status of its deliverables. To accomplish this, group members will meet periodically. The Senior Advisory Group consists of individuals from EG\&G Idaho, DOE-ID, DOE$\mathrm{HQ}$, other DOE sites, and the private sector.

\subsubsection{Planning, Oversight, and Coordination Committee}

The INEL TLD Planning, Oversight, and Coordination Committee participants provide guidance and recommendations to the INEL TLD project. Committee members are called upon to meet periodically to serve these functions. The committee consists of individuals from EG\&G Idaho, including representatives from the ER and WMO roadmapping teams.

\subsubsection{Principal Investigator}

Principal investigators (PIs) are responsible for developing technically sound deliverables that meet project milestones outlined in TTP ID-121117, reporting project progress to both linemanagement and the project manager, ensuring compliance of relevant regulatory and programmatic requirements, maintaining project coordination with project objectives, coordinating the activities of INEL TLD technical teams, and contributing to the generation of the INEL TLDs. In addition, the PI interfaces directly with INEL WAG managers to facilitate the transfer of information between the ER and WM Department and TD.

\subsubsection{Technical Contributors}

Technical contributors are responsible for providing specific technical expertise to support the PI in developing technically sound deliverables that meet project milestones outlined in TTP ID121117 and contribute to the generation of the INEL TLDs. In addition, the technical contributors must interface directly with INEL WAG managers to facilitate the transfer of information between ER and TD.

\subsubsection{INEL Roadmap Interface}

The INEL ER roadmap interface is assigned to support the INEL ER and WMO roadmapping teams for two reasons: (1) to gain an understanding of the technical and institutional technology needs, and (2) to communicate information obtained from the INEL TLD for integration into the INEL ER and WMO roadmaps to facilitate long-term TD planning.

\subsubsection{Computer Support}

Computer support personnel are responsible for inputing TLD data into project spreadsheet software (e.g., QUARK or MacFlow) and maintaining the software during the duration of the project. 


\subsubsection{Technical Team Leaders}

Technical team leaders will be identified for each subelement within the TLDs (e.g., characterization, treatment, etc.). Subelements, and therefore the number of team leaders, will be identified at a later date as the TLDs are developed. The responsibility of the team leaders is to (a) form and organize teams, (b) identify as many diverse contributors as possible (private sector, universities, etc.) to fill out technology data sheets, (c) serve as point of contact for all team members and contributors, (d) distribute, collect, and organize data sheets, (e) hold meetings with team members to provide collective evaluation and feedback on logic and objectivity, (f) contribute to the written TLD report, and (g) present project status to DOE-OTD.

\subsubsection{Technical Team Members}

The responsibility of the technical team members is to (a) fill out technology data sheets on an as-needed basis, (b) attend technical team meetings to obtain feedback on TD sheets, and (c) contribute to the written TLD report. 


\section{WORK SCOPE}

\subsection{Description}

The INEL will generate TLDs for its ER WAGs 1 through 7 and 10 to identify programmatic and institutional drivers that may affect INEL ER/WMO needs identification, identify specific INEL ER/WMO technology needs, assess if existing state-of-the-art technologies from the private sector, DOE complex, and other Federal agencies can potentially meet those needs, identify ER/WMO technology gaps, and provide input to developing a long-term TD strategy that can be integrated with the INEL ER/WMO roadmapping efforts to meet the overall INEL cleanup mission.

The work scope in this PjMP is based upon the work scope outlined in TTP ID-121117. ${ }^{2}$ The TTP identifies five main tasks to be accomplished in FY 1993. The five tasks are

1. Complete filter portion of TLDs

2. Complete technology portion of TLDs

3. Assemble TLDs

4. Deliver TLD report

5. ER and WMO roadmap support/integration.

\subsection{Filter Portion of Technology Logic Diagrams}

The identification of INEL ER and WMO technology needs and gaps and development of technological solutions are driven by a variety of programmatic and institutional constraints. Although a technology may offer promise from a technical standpoint to meet a particular need, it is possible that the development or integration of the technology may not meet customer requirements (e.g., regulatory, schedules, cost, etc.). Therefore, the identification and understanding of these constraints and/or requirements are crucial prior to developing TD strategies to meet the needs or gaps.

Hanford and ORNL developed a technology filter as part of their TLDs that serves to identify and screen technology needs and their potential solutions against programmatic and institutional constraints. The filter portion of the TLD is located at the front end of a TLD. An example of an ORNL TLD is illustrated in Appendix A. The filter portion of the TLD is the first five columns-EM Goals, EM Problems, Site Problems, Problem Area/Constituents, and Reference Requirements. The INEL TLD filter will differ slightly from the K-25 TLD filter because of different site problems, contaminants, and programmatic and institutional drivers.

The first project activity for FY 1993 is to develop the filter portion of the INEL TLDs for INEL ER WAGs 1 through 7 and 10: 
1. EM Goals. High-level EM goals for the cleanup of the entire DOE complex can be found in the ER and WM FY 1992-1996 Five-Year Plan. ${ }^{3}$ Additional sources of EM Goals include DOE-HQ EM personnel, DOE-ID EM personnel, and representatives from the K-25 TLD work at ORNL.

2. EM Problems. High-level EM problems throughout the DOE complex will be identified. Resources utilized to gain an understanding of EM problems include DOE-HQ EM personnel, DOE-ID FM personnel, Integrated Programs/Integrated Demonstrations Programs, and represe : tatives other DOE field offices.

3. INEL Site Problems. Many of the operable units (OUs) at the INEL have been designated as no actions and should not be included in the INEL TLDs. Project personnel will meet with ER representatives to gain a perspective of which OUs will most likely undergo remedial actions, and therefore, will be included in the INEL. TLDs. The OUs with the greatest likelihood of requiring remediation include those designated in the Environmental Protection Agency (EPA), State of Idaho, DOE Federal Facility Agreement and Consent Order (FFACO) ${ }^{4}$ as Track 2, Interim Actions, or Remedial Investigation/Feasibility Studies (RI/FS). Once OUs that will be included in the INEL TLDs are identified, specific site problems/conditions will be categorized accordingly. Examples of categories include evaporation ponds, injection wells, large-area surface contamination of soils, etc.

4. Problem Area/Constituents. Project personnel will meet with targeted INEL ER WAG and OU managers to determine what constituents contaminate each of the OUs that make up the site problem areas. The following information will be obtained for each OU within the selected site problem: a list of chemicals and contaminants, media contaminated (e.g., metal concrete, soil, etc.), configuration in which the contamination and the media exist, and the extent of the problem, such as volume, area, concentration, criticality, etc. The INEI. ER and WMO roadmaps provide a useful starting point for identifying ER and WMO problems and will be utilized in this project. Participants in this study will work in concert with INEL ER roadmap and ER waste stream tracking personnel to identify items such as ER and WMO planning assumptions, issues, schedules, regulatory requirements, etc. that are ancillary information in identifying problems. Every effort will be taken to ensure that problem statements are as comprehensive and quantitative as possible in accu dance with ER needs. A rigorous problem assessment at this stage will facilitate the subsequent identification and statusing of technologies.

5. Identify Reference Requirements. Institutional and programmatic documents identify regulatory drivers (e.g., remediation schedules), applicable regulatory requirements, and end state requirements for each problem area listed. Examples of documents include the FFACO, DOE orders, and Comprehensive Environmental Response, Compensation, and Liability Act (CERCLA).

The project manager, PI, and technical contributors will assume the responsibility to complete the filter portion of the INEL TLDs. The front-end filter of each TLD (WAGs 1 through 7 and 10) will be completed and submitted to INEL ER and WMO, ORNL X-10 project, and TLD Steering Group for review and subsequent guidance. 


\subsection{Technology Portion of Technology Logic Diagrams}

Completing the second half of a TLD involves gathering and evaluating information on state-ofthe-art technologies that could be used to remediate the various site problems. The remaining columns on the TLD (see Appendix A) include Subelements, Alternatives, Technologies, Status, Science Technology Needs, and Implementation Needs. Some of this information may be gathered from the previously mentioned Hanford document ${ }^{1}$ and from the K-25 and X-10 site TLD work performed at ORNL.

1. Subelements. The subelements proposed are discrete remediation steps needed to remediate a problem area. Examples of subelements include characterization, retrieval, and in situ and ex situ treatments. A team leader and technical team will be formed for each INEL TLD subelement.

2. Alternatives. Options or generic approaches are proposed that are subsets of the subelements required to correct each site problem. For example, for the subelement characterization, alternatives may include in situ characterization, geophysical characterization, or analytical laboratory characterization. Project personnel will interview WAG and OU personnel to understand current outyear budgeting assumptions that may drive the type of remediation currently planned for a particular site problem.

3. Technologies. Suitable technologies are proposed with the likelihood of solving problems within the identified technical restraints (site problems), programmatic constraints (subelements, alternatives), and institutional constraints (reference requirements).

4. Technology Status. Technologies are categorized based on their maturity level in the following manner:

- Existing-Technology accepted by industry and/or regulators and the demonstrated technology exists for use at the INEL.

- Demonstrated-Technology available but not demonstrated and/or accepted at the INEL.

- Predemonstration-Technology currently under laboratory, bench, or pilot scale testing.

- Evolving Technology-Status at a conceptual, preconceptual, or problem definition stage such as:

- Conceptual-Knowledge base exists.

- Preconceptual-Basis of technology does not exist; only a partial knowledge base exists.

- Problem definition-Functional requirements of a technology are not defined, i.e., defining what the technology is required to do. 
In addition, the following will be addressed in the explanation of each technology:

- Is the technology likely to work and how well? What are its recognized limitations? For characterization goals, for example, numeric ranges or limits that the technology can achieve in routine practice will be indicated.

- Nature and quantity or relative quantity of waste generated.

5. Science and Technology Needs. Specific science needs are defined for those technologies in the evolving or predemonstration phases. TD needs are identified for those technologies in the predemonstration or demonstration phases. Finally, technology improvement needs are identified for those technologies that have been previously demonstrated or accepted.

6. Implementation Needs. Prerequisites to successful TD or improvement before it is demonstrated or accepted are identified. Status of implementation needs in the process of being implemented are also identified. The following items are examples of items considered under this column: cost and cost benefit potential, resources (financial, personnel, demonstration, procurement, etc.), hardware needs (equipment, computers, etc.), software needs (models, procedures, etc.), facility needs (labs, shops, buildings, etc.), educational needs (classes, degreed graduates with defined majors, etc.), and reference requirements (additions or modifications necessary to deploy the technology successfully).

The INEL TLD technical teams will be requested to complete the technology portion of the INEL TLDs based upon information contained in the filter portion of the TLD. ORNL has developed a TLD Data Sheet (see Appendix B) that aids in the collection of information required in a TLD. The Data Sheet asks for the same information as identified in the columns of a TLD, except in a user-friendly format. Therefore, the technical teams do not have to be concerned with transforming data into the TLD format. The completed filter portion of the TLD Data Sheet (the first five column headings of a TLD) will facilitate the completion of the remainder of the form by the technical teams.

Several areas of the TLD Data Sheets, and therefore, the TLDs will require documentation to support conclusions or document assumptions. Documentation may range from "personal opinion assuming the following; "personal communication from..."; calculation based upon..."; to a report, open literature reference, or commercial information publication.

The technology portion of each TLD (WAGs 1 through 7 and 10) will be completed and submitted to INEL ER and WMO, ORNL X-10 project, and TLD Steering Group for review.

\subsection{Technology Logic Diagrams}

ORNL has experience in constructing TLDs, and they have experience using the QUARK software package to transfer information from TLD Data Sheets into TLDs. INEL will collaborate with ORNL and use the QUARK or a similar software to assemble the INEL TLDs. The project manager will solicit support from the private sector with computer experts to input data and construct, modify, and maintain the TLDs. 


\subsection{Deliver Technology Logic Diagram Report}

A report will be generated that presents the INEL TLDs and all supporting information. The report will be a valuable resource and will serve to (a) define ER and WMO technology needs or gaps that are representative of arid DOE sites, (b) status the ability of currently available technologies to meet those needs, (c) characterize the link between DOE-EM needs and EM-50 research activities, (d) characterize the link between EM long-term strategic planning and current ER and WMO roadmapping efforts, and (e) leverage DOE resources within Integrated Programs/Integrated Demonstration Programs to meet EM technology needs or gaps.

After an INEL ER and WMO review, the report will be distributed to all Integrated Programs/Integrated Demonstration Programs as input for FY 1994 "Call For Proposals." In addition, results from the report will be presented at an Industrial Workshop to be held at the INEL, tentatively scheduled for August FY 1993. The workshop will be used as a forum to disseminate information on INEL ER and WMO technology needs or gaps to the private sector to encourage and facilitate future industrial participation at the INEL and other DOE sites. The INEL will work with the ORNL X-10 project to develop a standardized data base containing INEL and eventually INEL and ORNL TLD results. Interested parties within and outside the DOE complex would have access to the data base.

\subsection{ER and WMO Roadmap Support/Integration}

Draft INEL ER and WMO roadmaps have identified regulatory drivers, issues, and programmatic assumptions affecting the environmental restoration and proper management of wastes at the INEL. Enhancements to the INEL ER and WMO roadmaps in the area of TD have been proposed by DOE-HQ. An individual will be assigned from the project to support the INEL ER and/or WMO roadmapping team for two reasons: (1) to participate in WAG and Waste Stream Manager roadmap interviews to understand the technical (waste volumes, contaminant concentrations, etc.) and institutional (regulatory considerations, remediation schedules, budgeting constraints, etc.) aspects of technology needs, and (2) to integrate information obtained from the TLD task into the INEL ER and WMO roadmaps to facilitate long-term TD planning. This individual will also dedicate an appropriate amount of time to the INEL TLD project. 


\section{WORK BREAKDOWN STRUCTURE AND RESPONSIBILITY ASSIGNMENT}

\subsection{Project Work Breakdown Structure}

The Work Breakdown Structure (WBS) for the project (TTP ID-121117) is shown in Figure 3. The major elements of the project WBS are described in Section 4. Logic diagrams implementing activities to produce deliverables are shown in Section 7. A responsibility matrix was not generated since the project manager will have the responsibility for delegating work to others. WBS Element 1.0, Project Management, is described in several sections of this PjMP but is addressed below for continuity.

Element 1.0-Project Management. The project will operate, as applicable, in accordance with the intent of DOE Orders 4700.1 and DOE Order 2250.1C, as implemented by EG\&G Idaho Company Procedures Manual, Volume IV, Section 20. Appropriate management and control systems will be implemented for each work element of the WBS to comply with the requirements of the applicable procedures.

WBS Element 1.1-Environmental Checklist. Project activities will be evaluated for environmental compliance as specified in DOE/ID 10166. This will be done by completing an Environmental Checklist (DOE Form IDF 5440.1a). An evaluation of the checklist by EG\&G Idaho Environmental Technical Support will recommend what further action is necessary. DOE-EH-1 will determine the level of National Environmental Policy Act (NEPA) documentation required.

WBS Element 1.2-Reporting. This project has reporting requirements to effectively monitor and document programmatic activities. Monthly reporting (WBS Element 1.2.1) will take place at the TTP level, providing status relative to the established performance measurement baseline (PMB). Cost or schedule variance reports of $\pm 10 \%$ or $\pm 50 \mathrm{~K}$ will require analysis of cause impact and corrective action. Weekly (WBS Element 1.2.2) and monthly reports will be transmitted to DOE-HQ through DOE-ID. Content will include weekly highlight reports, consisting of significant accomplishments and programmatic issues, from the PI and project manager. Reporting requirements will be included in Work Releases or Task Baseline Agreements with functional support staff from other organizations within the Company.

WBS Element 1.3-Project Documentation. This WBS element describes the preparation of documentation for establishing work scope, schedule, and cost baselines for the project. This includes preparation of project's TTPs (WBS Element 1.3.1), work packages (WBS Element 1.3.2), and PjMP (WBS Element 1.3.3). 


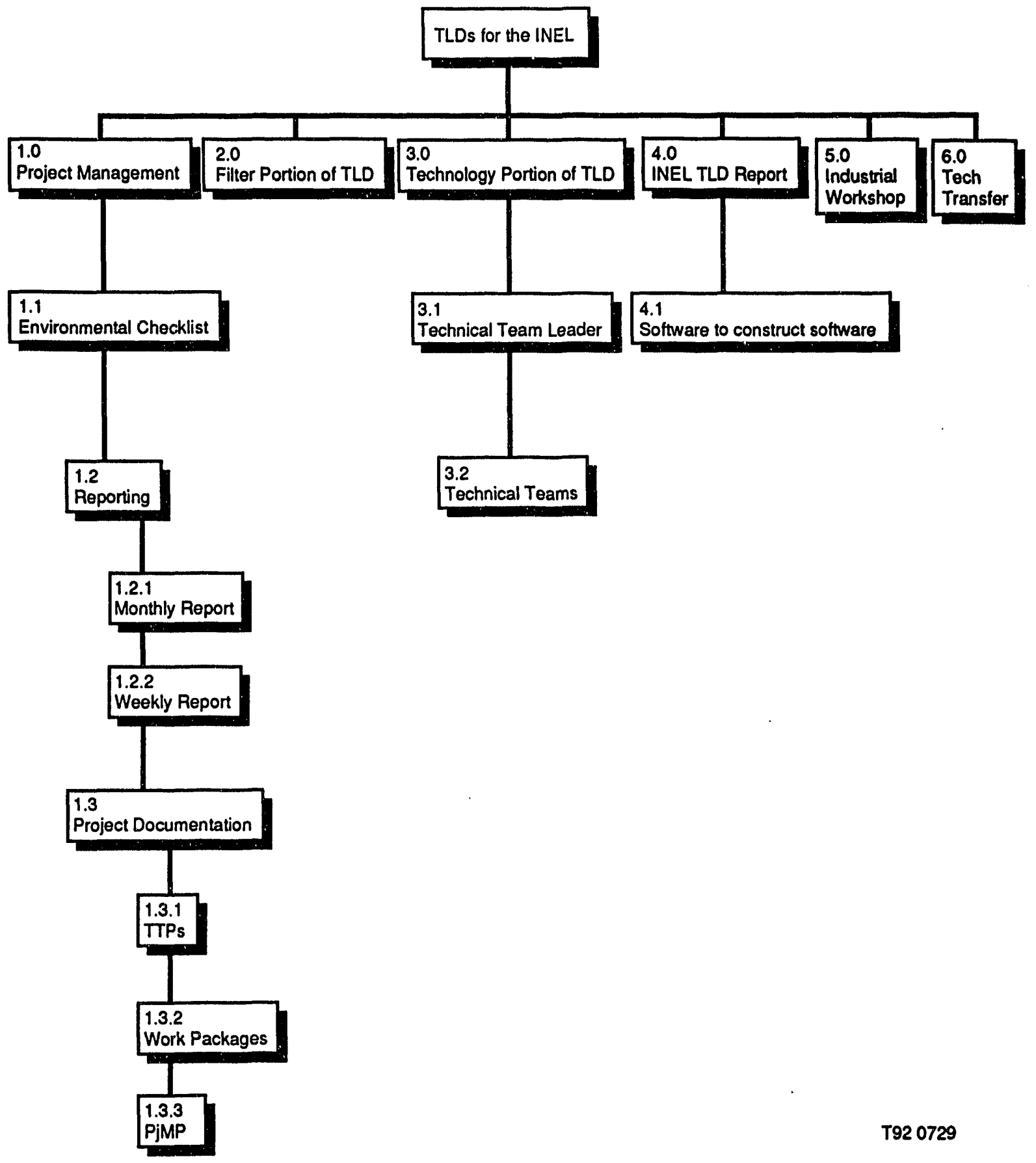

Figure 3. WBS for INEL TLD project. 


\section{SCHEDULE}

The following schedules (see Tables 1 through 5) identify interim project deliverables to support planned and key milestones in TTP ID-1211172. 


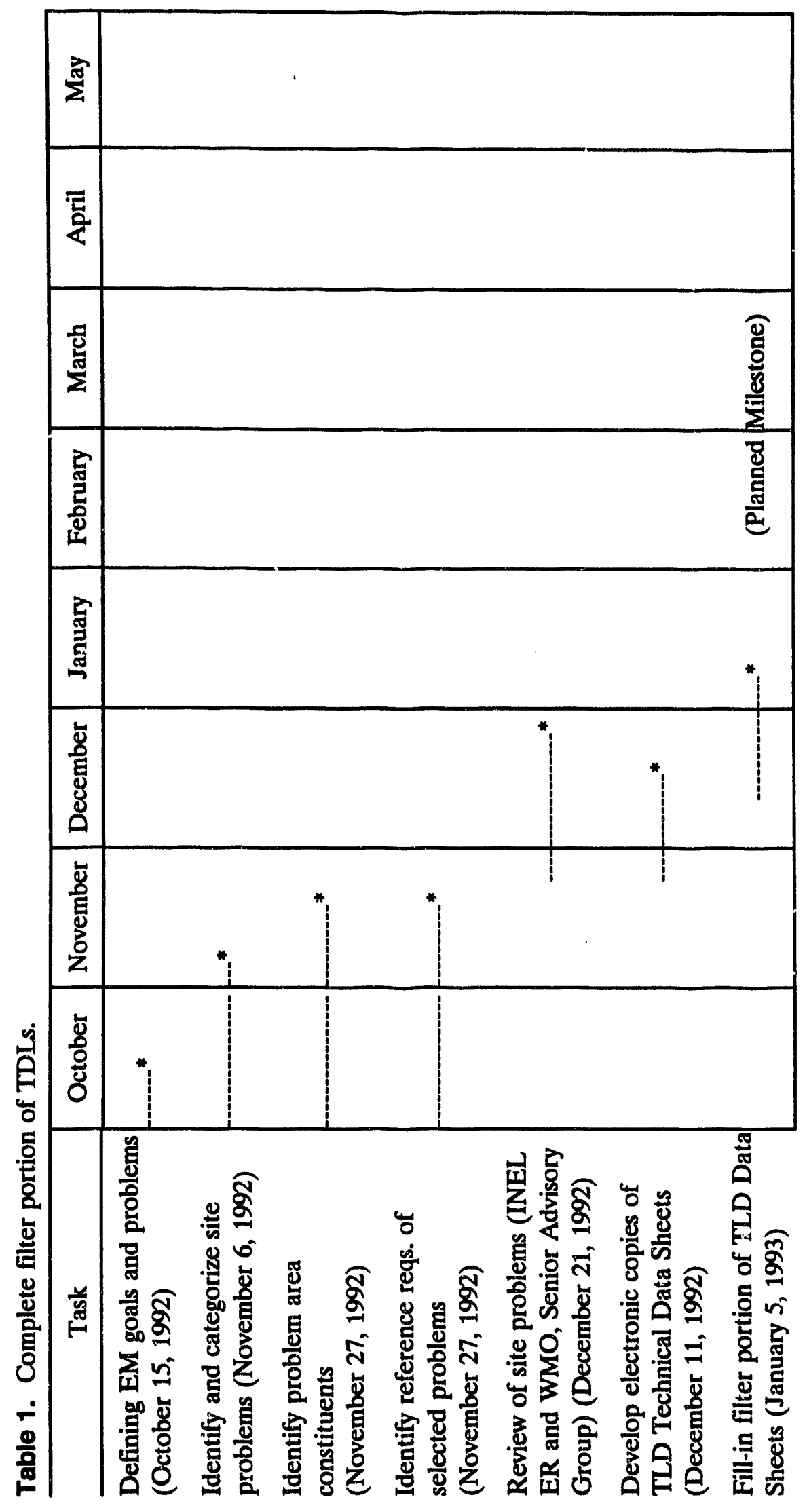




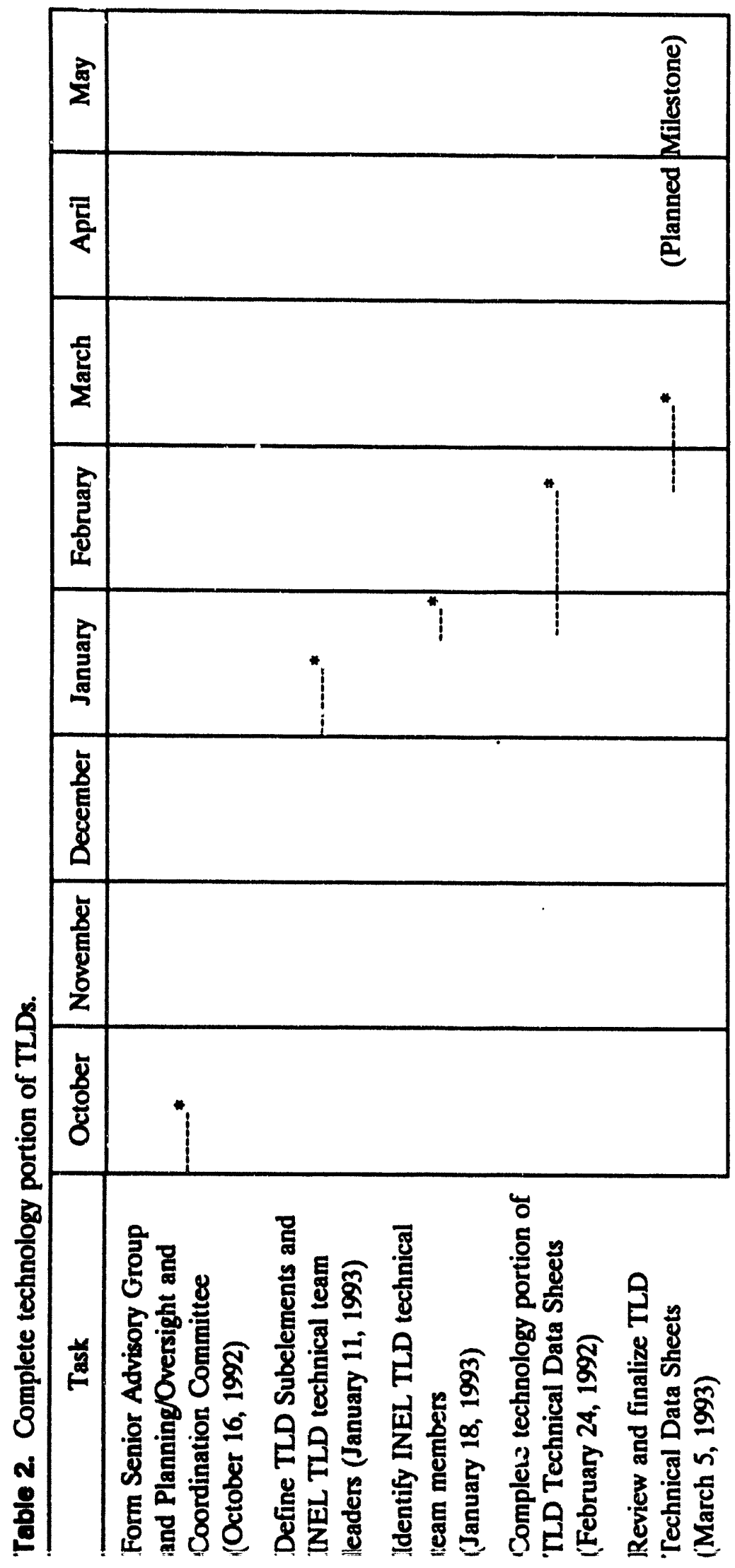




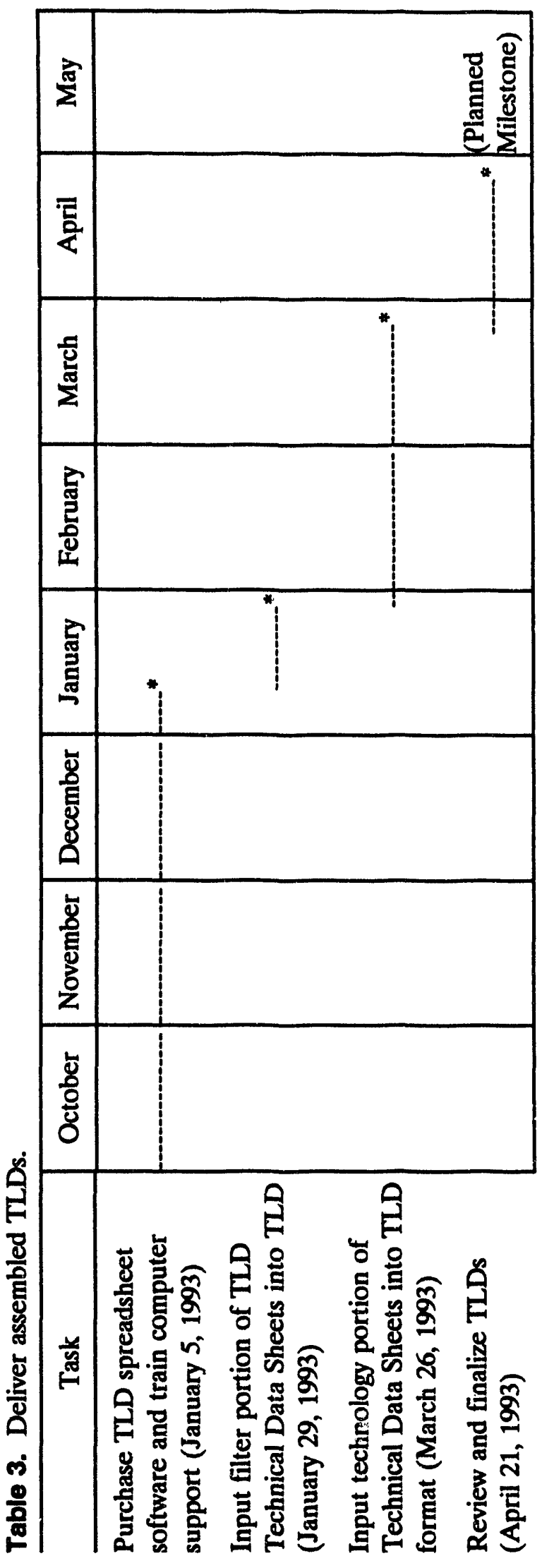




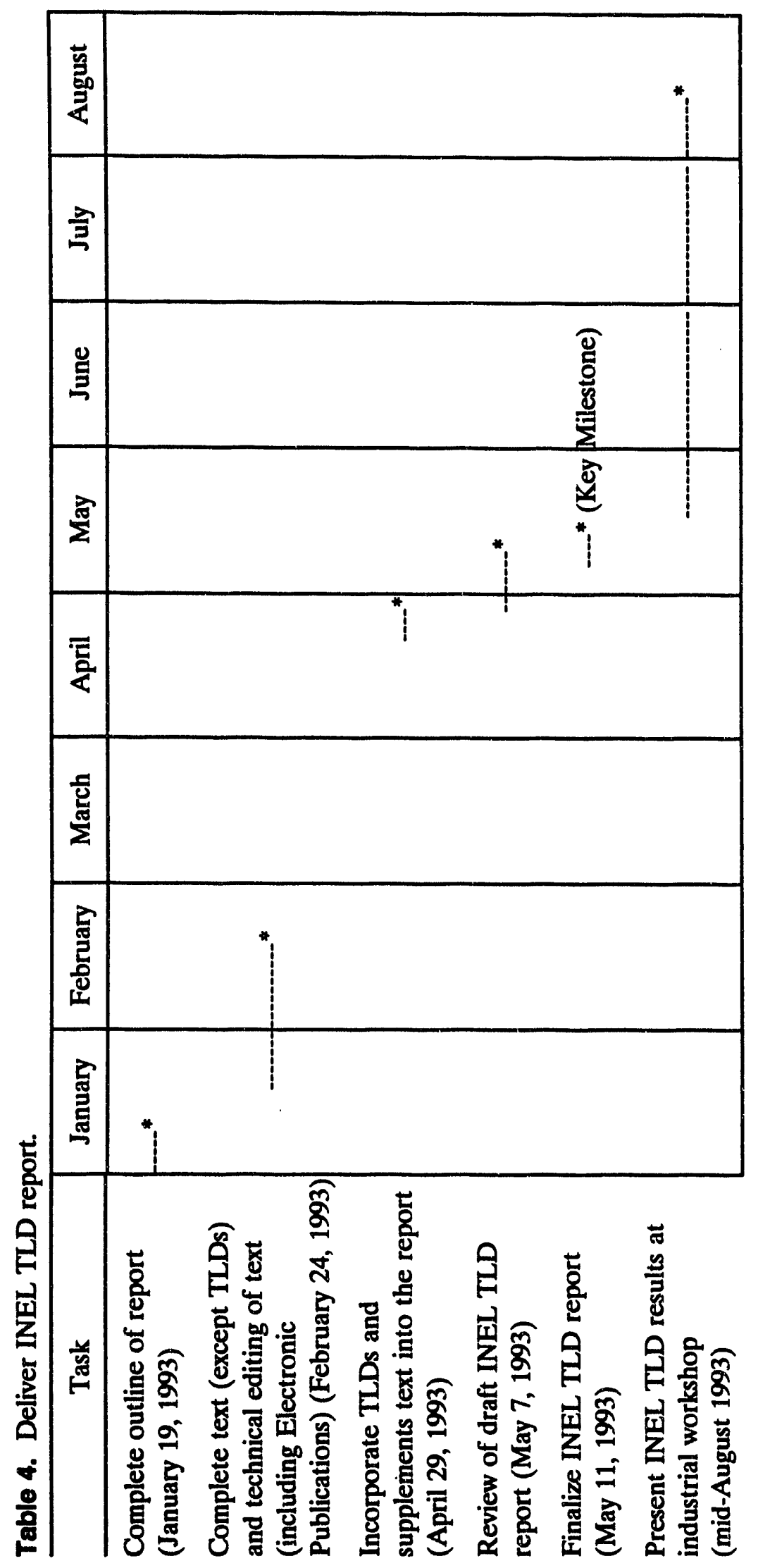




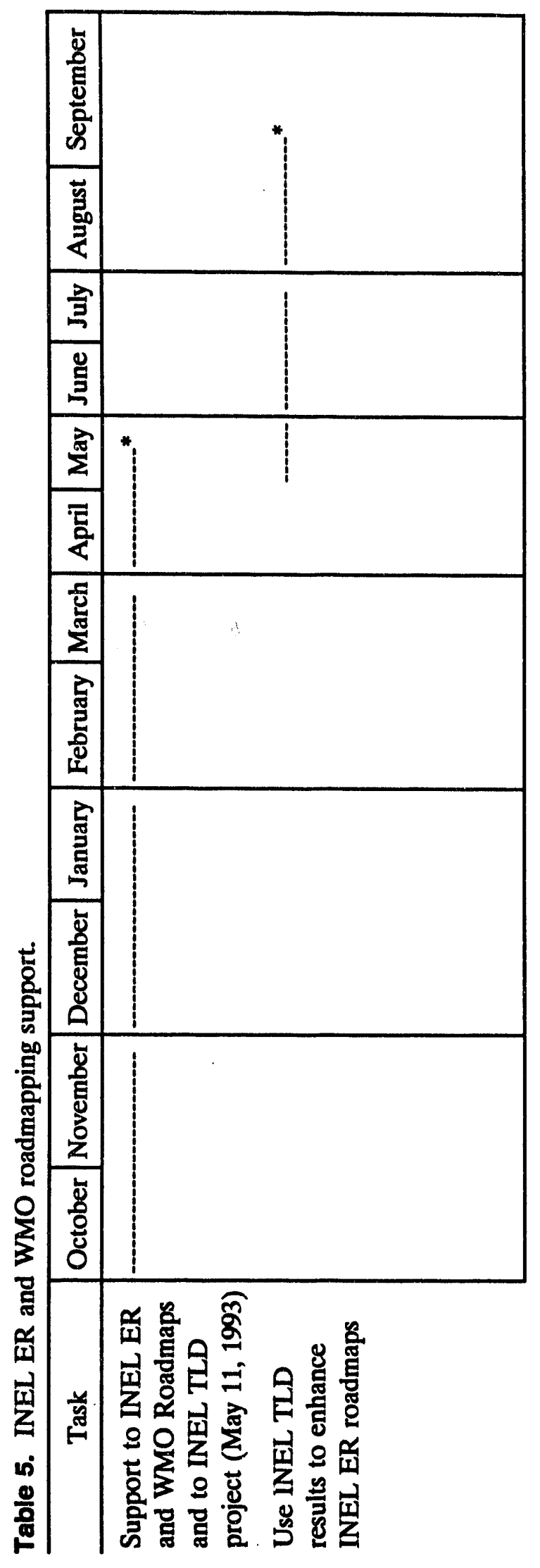




\section{LOGIC DIAGRAMS}

Logic diagrams provide a mechanism to track the progress of major tasks, deliverables, and planned and key milestones for this project. Logic diagrams for this project can be found in project work packages prepared in accordance with TTP ID-121117. 


\section{PERFORMANCE CRITERIA}

The ultimate measurement of success for this project will be the integration and/or implementation of technologies by EM-50 to meet technology gaps or needs in support of EM-30 and EM-40. Results from the INEL TLD project will focus PIs, throughout the DOE complex, to develop and demonstrate technologies (within Integrated Program/Integrated Demonstration Program) for eventual use within EM-30 and EM-40. In addition, results will indicate those technologies, currently existing in the private sector that are ready for implementation into EM-30 and EM-40 activities. 


\section{COST AND MANPOWER ESTIMATES}

Tables 6 and 7 depict cost and manpower estimates based on TTP ID-121117.

Table 6. INEL TLD project cost estimates (\$K).

$\frac{F Y 1992}{\$ 50 \mathrm{~K}} \quad \frac{\text { FY } 1993}{\$ 610 \mathrm{~K}} \quad \frac{\text { FY } 1994}{0} \quad \frac{\text { FY } 1995}{0} \quad \frac{\text { FY } 1996}{0}$

Table 7. INEL TLD project labor estimates (full-time equivalent).

$\frac{\text { FY } 1992}{.05} \quad \frac{\text { FY } 1993}{3.0} \quad \frac{\text { FY } 1994}{0} \quad \frac{\text { FY } 1995}{0} \quad \frac{\text { FY } 1996}{0}$




\section{PROJECT FUNCTIONAL SUPPORT REQUIREMENTS}

The TLD for the INEL project (TTP ID-121117) is funded by DOE OTD. This PjMP addresses functional support requirements of TTP ID-121117 only. Project direct staff includes the project manager, a PI, technical contributors, and additional administrative and support staff to perform specific project functions.

Additional support within EG\&G Idaho will be defined in the project work packages and is obtained by a matrix management arrangement with other departments to conduct various technical and project specific support tasks. A Task Baseline Agreement or Work Release is required for all work performed by support organizations. Specific requirements of the Task Baseline Agreement or Work Release are included in the WTD Program Management Plan and Program Directive 2.3, "Project Management Requirements and Restraints." 


\section{PROJECT MANAGEMENT, MEASUREMENTS, AND PLANNING AND CONTROL SYSTEMS}

The project will operate, as applicable, in accordance with the intent of DOE Order 4700.1, and DOE Order 2250.1C, as implemented by EG\&G Idaho Company Procedures Manual, Volume IV, Section 20. Appropriate management and control systems will be implemented by the project team for each work element on the WBS to comply with the requirements of the applicable procedures. This applies to whether the work element is performed at the INEL or at other DOE sites. The project manager has the authority and responsibility to develop and maintain management planning, performance measurement, and control criteria and applicable procedures.

This PjMP is the administrative baseline document for this project and is modified only through the formal change control process. Technical scope baselines, WBSs, costs, schedules, change processes, and management control systems are enacted by the PjMP, TTP, and work packages. General project management responsibilities are defined for this project in the WTD Program Directive 2.3.

A DOE-ID approved financial plan, which authorizes funds for a project, must be in place before initiation and authorization of any work to be performed. Work packages must also be in place and approved by the Change Control Board (CCB) before any work begins. Monitoring of the project work packages will be performed using the following tools and processes:

- Cost and Planning System (CAPS) labor hours and distribution report to document actual hours spent weekly

- Projected and expended cost comparison curves (PMS-IV) to display work packages costto-schedule performance

- Weekly monitoring of actual costs and understanding commitments

- Biweekly status of work package and WBS activities to show progress to completion. 


\section{INFORMATION AND REPORTING}

\subsection{Reporting Requirements}

The project will operate in accordance with DOE Order 1332.1A, "Uniform Reporting System," EG\&G Idaho Resource Manual, Section 10, "Documentation Systems," WTD Program Management Plan, Section 7, "Reporting and Change Control," WTD PD 1.5, "Document Preparation, Review, Approval, Publication, Management and Change Control," and WTD PD 5.3, "Preparation and Control of WTD Monthly Status Report." These documents control processing of status reports; internal, informal, and formal reports; and formal and informal communications.

\subsection{Weekly and Monthly Reports}

This project has additional reporting requirements to effectively monitor and document programmatic activities. Monthly reporting will take place at the TTP (Cost Account) level and will provide status relative to established project costs, schedules, and technical baselines. Cost or schedule variance reports of $\pm 10 \%$ or $\pm 50 \mathrm{~K}$ will require analysis of cause impact and corrective action.

Weekly and monthly reports will be transmitted to DOE-HQ through DOE-ID. Content will include weekly highlight reports from the PI and project manager. Reporting requirements will be included in Work Releases or Task Baseline Agreements with functional support staff from other organizations within the Company. 


\section{SYSTEM ENGINEERING MANAGEMENT PLAN}

This project is not a Major System Acquisitions or a Major Project, therefore this section does not apply. 


\section{CONFIGURATION MANAGEMENT}

Configuration management for this project will be implemented in accordance with Waste Technology Development (WTD) Directive 3.3, "Configuration Management." Change control within the INEL is provided by means of a CCB, which has been established by a draft WTD Program Management Plan. The purpose of the CCB is to control changes to the EG\&G Idaho WTD's baseline (customer-directed and/or agreed upon changes to the project effort), document internal changes to the performance measurement baseline, and prohibit retroactive changes to records pertaining to work performed. 


\section{CONTINGENCY PLANNING}

This element addresses the formal and informal assessment of risk in each project activity and the associated contingency planning to cover the elements/activities perceived as high risk. There is no contingency funding identified for this project. 


\section{QUALITY ASSURANCE}

The project will adhere to the WTD Quality Program Plan QPP-337 "Quality Program Plan for the Waste Technology Development Department" dated November 12, 1991. Work performed elsewhere will be required to show that an equivalent level of quality will be implemented and maintained. 


\section{UTILITY SERVICES}

No additional utility services or modifications to the existing services are required for this project. 


\section{DECISION RESPONSIBILITY MATRIX}

Because of the small size and number of individuals involved in this project, it was determined that a responsibility assignment matrix would not be cost effective. 


\section{ENVIRONMENTAL PLAN}

Project activities will be evaluated for environmental compliance as specified in DOE/ID 10166. This will be done by completion of an Environmental Checklist (DOE Form IDF 5440.1a). An evaluation of the checklist by EG\&G Idaho Environmental Technical Support will recommend what further action is necessary. DOE-EH-1 will determine the level of NEPA documentation required. 


\section{HEALTH AND SAFETY PLAN}

The EG\&G Idaho Inc. Safety Manual shall be used for this project. Existing health and safety plans at facilities performing work shall be used if such plans exist. All safety plans shall include observance of the Occupational Safety and Health Administration (OSHA) standards and requirements and all Federal, state, and local codes. If no safety plan exists, the EG\&G Idaho Safety Manual shall be used as the basis for a plan that will be written. 


\section{SECURITY PLAN}

The Security Plan shall follow the guidelines outlined in the EG\&G Idaho Safeguards and Security Manual. At each facility where work is to be performed, security shall follow the plan that is currently in place for that facility. Where no plan exists, or it does not cover the specifics of the work to be performed, a Facility Security Plan or a Project Security Procedure will be written and included as a part of this PjMP. These will be issued before starting the work, in accordance with the EG\&G Idaho Safeguards and Security Manual. 


\section{TECHNOLOGY TRANSFER}

It is the responsibility of every project manager to plan for the eventual transfer of technology. Only the TLD methodology developed during the course of this project is information that has potential for technology transfer to benefit private industry. It is more likely that the methodology would be transferred to other Federal agencies and DOE field offices. The project manager will work closely with DOE-ID and the Office of Research and Technology Applications to facilitate any potential technology transfer initiatives. 


\section{DATA QUALITY PLAN}

The project manager has oversight responsibility for data quality management. This includes the establishing an adequate data management system. Data quality will be ensured by specifying requirements for data in terms of precision, accuracy, representativeness, completeness, and comparability. Detailed information related to data quality is discussed in the EPA, OSWER 9355.0-7B, "DQOs for Remedial Response Activities." Guidelines for ensuring auditability, traceability, and data integrity may be found in OWSER 935.3-01, "Guidance for Conducting RI/FS Under CERCLA." Data control will be implemented in accordance to INEL ER Directives 1.8, "Administrative Record," 1.9 "Records Management," and 2.4, "Characterization Process in the Environmental Restoration Program."

Documents generated will be controlled in accordance with WTD Program Directives 1.4, "WTD Records Management Plan," 1.5, "Document, Preparation, Review, Approval, Management and Change Control," and 1.6 "Engineering Design File." 


\section{ACQUISITION AND ASSISTANCE PLAN}

The process by which the project identifies material needs, performs the acquisition of materials, and performs the handling and control of material will be consistent with EG\&G Idaho procurement processes. The project manager/PI will submit requisition, and EG\&G Idaho procurement is then responsible for issuing and managing subcontracts and purchase orders. 


\section{TEST AND EVALUATION PLAN}

A Test and Evaluation Plan will not be developed for this project. All project deliverables and activities will be evaluated by appointed review groups for completeness and technical soundness.

Letter reports to the DOE-ID project manager describing the results from the independent reviews will be generated. 


\section{REFERENCES}

1. Westinghouse Hanford Company, The Hanford Model: Environmental Cleanup Problems, Science, and Technology Needs and Facility Requirements, PNL-7807/WHC-MR-0282.

2. Technical Task Plan, ID121117, Revision 0, EG\&G Idaho, Inc., "Technology Logic Diagrams For The INEL," 1992.

3. U.S. Department of Energy, Environmental Restoration and Waste Management Five-Year Plan, FY 1993-1997, August 1991.

4. Idaho National Engineering Laboratory, Federal Facility Agreement and Consent Order, ADN: 1088-06-29-120, May 1991. 


\section{Appendix A}

\section{Portion of ORNL K-25 Technology Logic Diagram}




\section{Technolk}

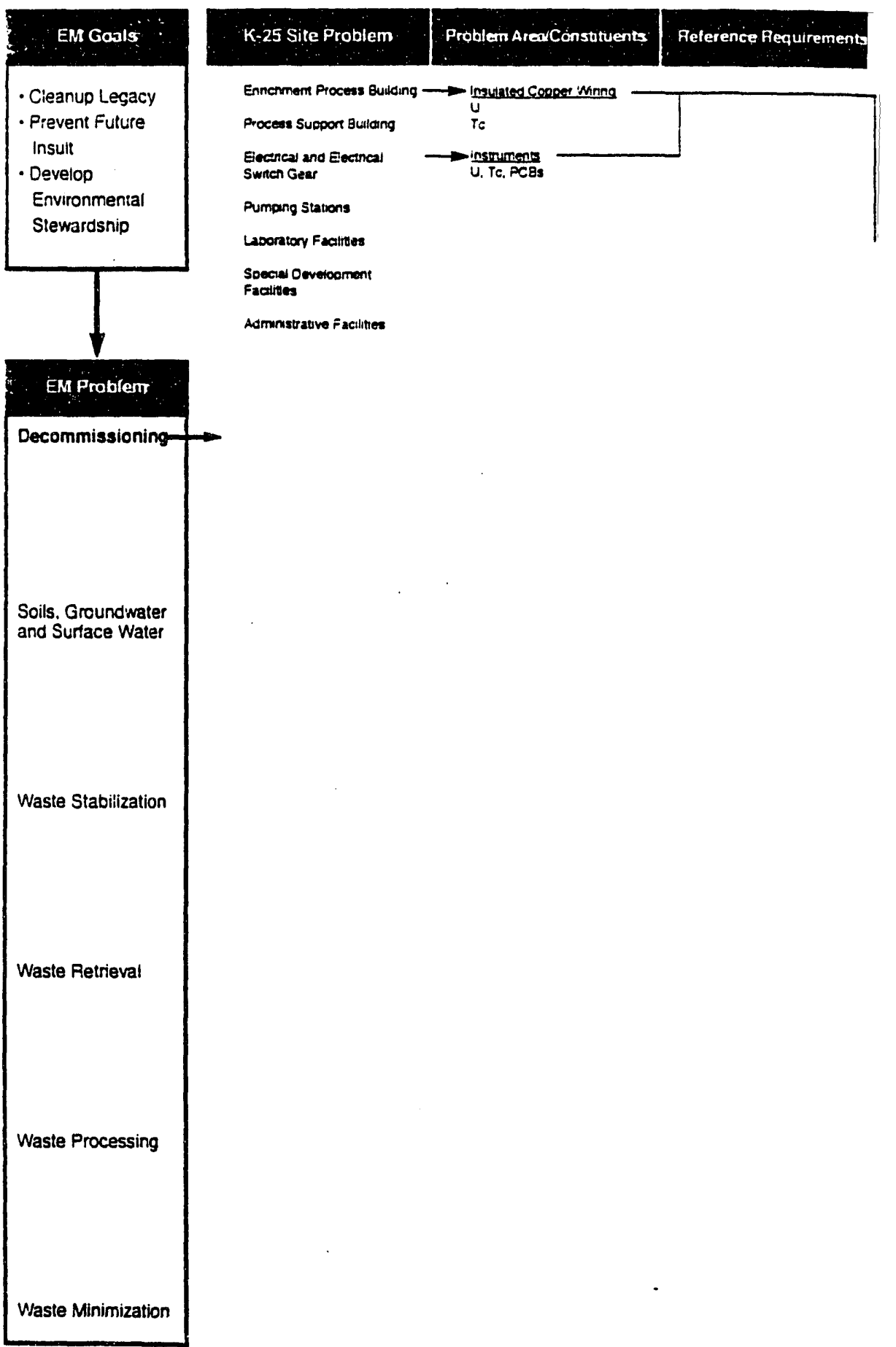




\section{gy Logic Diagram \\ Decontamination}

Sub Elements
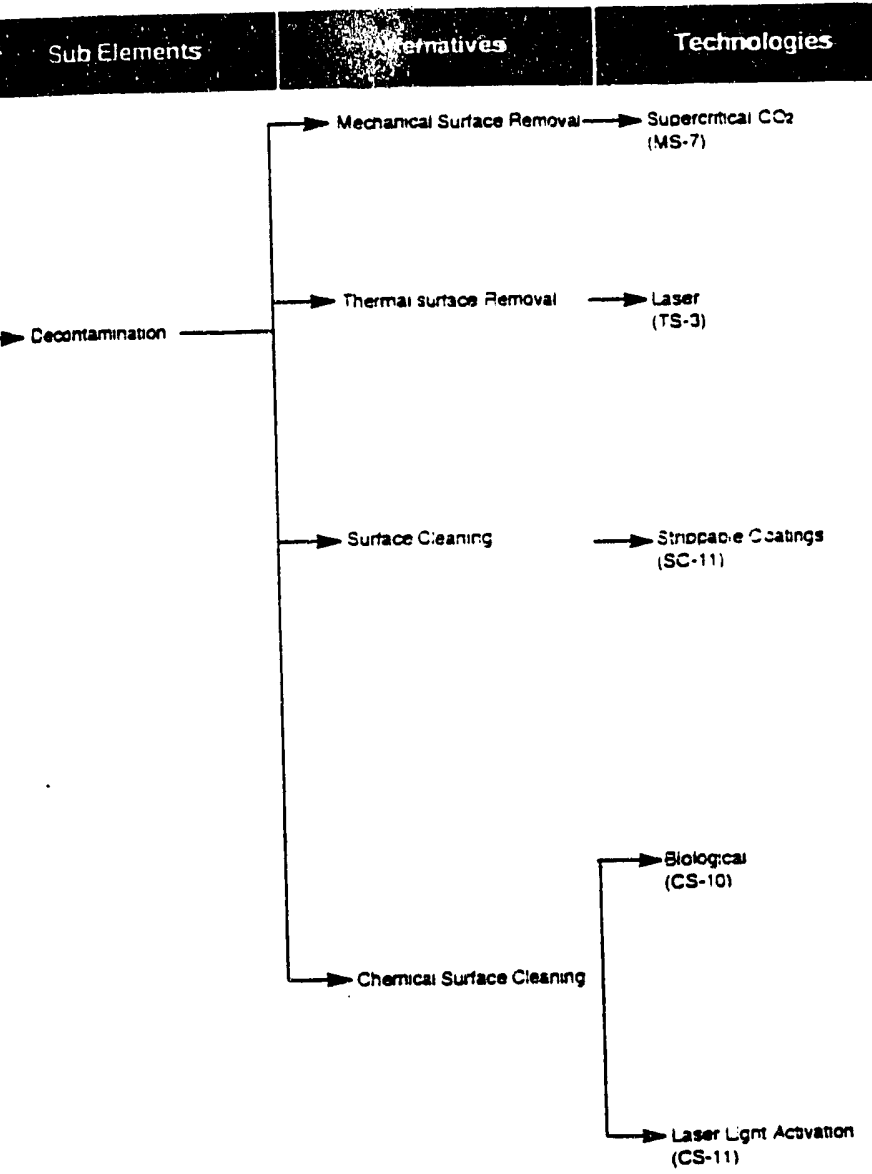

Technologies

Status

Science Technology Needs

Implementation Needs
$\rightarrow$ Predemor stravon
Beng ceveroped by FLCW
Coro eftective
ness remeuns io be semon
strated: waste whll be pro
filters and HEPA filters niled
whth contaminants

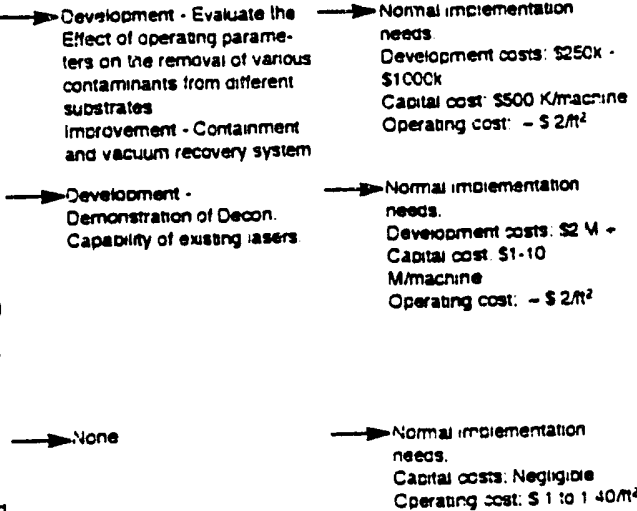

$\rightarrow$ Covatocmem - Evaluate the $\rightarrow$ Nonnal imciementauon Elfect of operaung parameiers on tie removal or vanous contaminants

substratos

imsiovernem - Comtanmem and vecuum recovery system

$\rightarrow$ Devetooment.

Demonatration of Decon. Capanity of exusung lasers

needs

Develocment costs: $525 \mathrm{ck}$.

s1cock

Cacital cor $5500 \mathrm{Kmacsine}$

Operang cost: $-52 \mathrm{~m}^{2}$

$\rightarrow$ Norma imoiememation

noecs.

Ceveroomem sosts: $2 \mathrm{~K}$.

Cadita cost 51.10

M/macrine

Operaung cost: $-\$ 2 m^{2}$

$\longrightarrow$ ivone

$\rightarrow$ Normal imsiementation

needs.

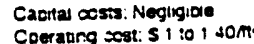

Working
Qrapt

C...

Demonstraton

Currenty sems eraluated oy Ar foros as a molnos lor tomeving organuc cosungs from metal. aurrent systems are cacene of removing $2-m$ theck ceasngs at re rate of 100 in atr. waste mil be ore fitters anc HEPA titers filles with cennminants

Teconnciogy has been used

for cetortamination appica.

thons irvoivng nazarcous and

racioassie coniaminants

Decontanination factors of

one 10 several nuncrea can

be exferece wion two applica-

thors. Finste is a solid coly-

mer (velume a $1 \mathrm{~mm} x$ sur.

face ale decontamunated)

comainuxg the removed cont. amnant3.

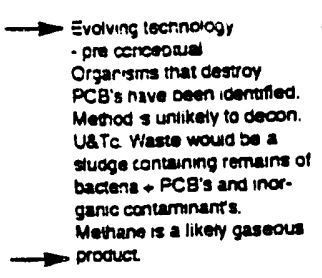

procuct

Evolvins tectnotogy Acceturest of reacon rates tor seiected reacions is proven. Small scale decon proven. Smal scale docon

Whate rould be pretiners and

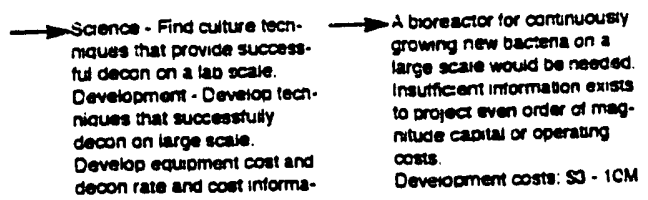
ton.

Devetopment -

Cemonetrition of vecuum

system capabie of collecerng removed contamnants.
Norma imolementution neecs. Deverooment $\infty$ sts: $22 M$ Castar cost: $51 \cdot 10$

Mimectrine

Operaung cost: Unknown

HEPA itters tiried inth 


\section{Appendix B}

\section{Technology Logic Diagram Data Sheet Example}




\section{Appendix B}

\section{Technology Logic Diagram Data Sheet Example}

Name

Organization

Address

Team Leader

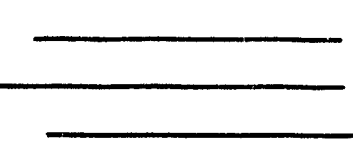

Phone No.

May 18, 1992

FAX No.

E-Mail

TECINOLOGY LOGIC DIAGRAM INPUT DOCUMENT Waste -.....-.

EM PROBLEM: Waste -...-.--

PROBLEM AREATARGET CONSTITUENTS/MEDIA:

REFERENCE REQUIREMENTS: Document!

SUBELEMENT: Waste

GENERIC TECHNOLOGY:

SPECIFIC TECHNOLOGY:

TECHNOLOGY STATUS: Document!

SCIENCETECHNOLOGY NEEDS: Document!

IMPLEMENTATION NEEDS: Document! 

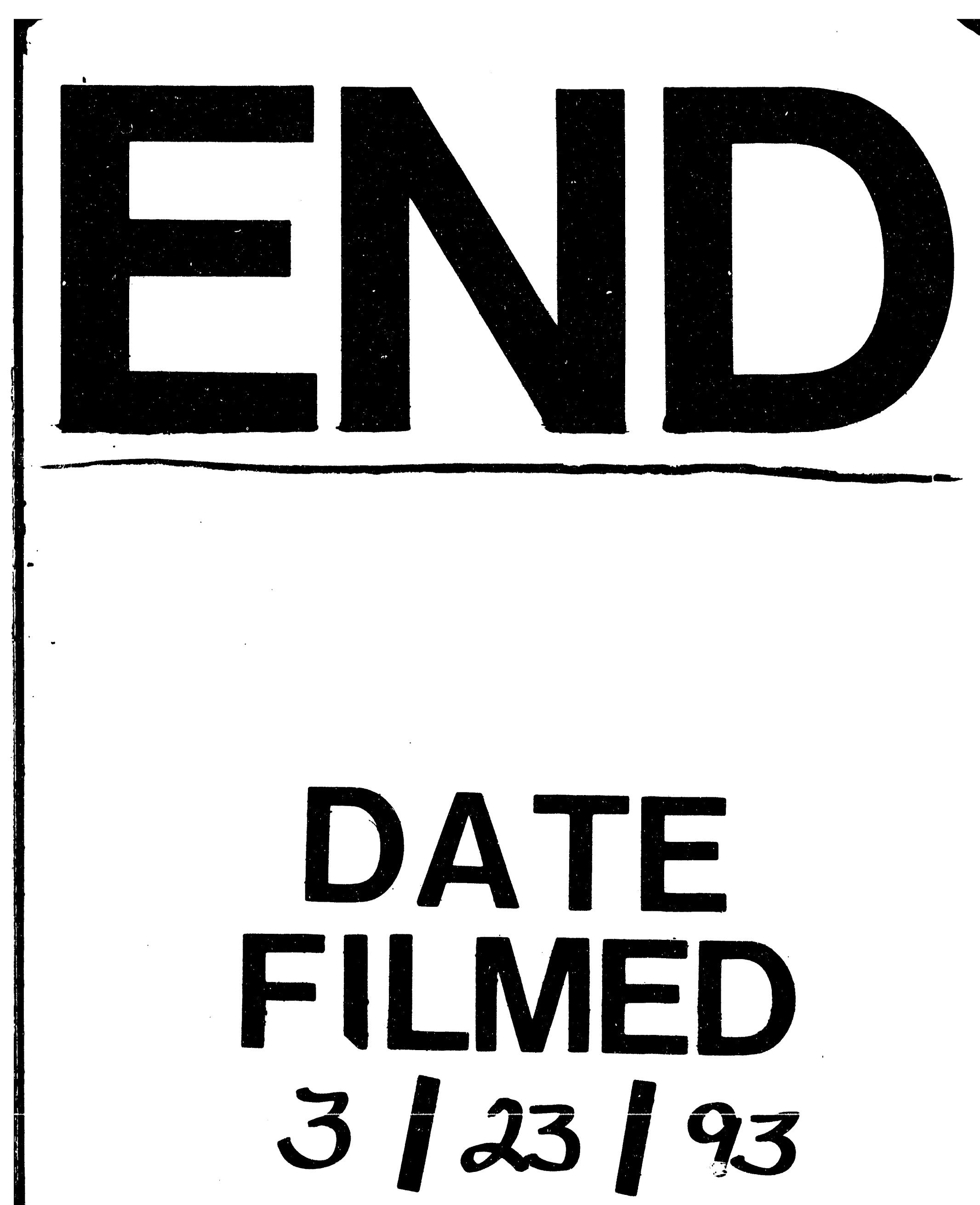
衰

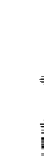

